\title{
Potential Impact of Long Term Use of Integrated Nutrient Management Practices on the Population of Azotobacter and Azospirillum spp. and urease activity to Sorghum-Wheat Sequence in Vertisol
}

\author{
Nilam B. Kondvilkar ${ }^{1 *}$, S. R. Patil ${ }^{1}$, A. L. Pharande ${ }^{1}$, B. D. Bhakare ${ }^{1}$ and A. M. Navle ${ }^{2}$ \\ ${ }^{1}$ Department of Soil Science and Agricultural Chemistry, ${ }^{2}$ Department of Plant Pathology \\ and Agricultural Microbiology, Mahatma Phule Agricultural University, \\ Rahuri. -413 722 (M. S.), India \\ *Corresponding author
}

\section{A B S T R A C T}

The cultivated soils have heterogeneous environments in which the soil conditions affecting microbial population, its growth and diversity fluctuate very widely in space and time and that regulate nutrients availability and crop productivity. In present study, the

\section{Keywords}

Azotobacter and Azospirrilum spp. population, Urease activity, Available N, INM, Long-term fertilization

\section{Article Info}

\section{Accepted:}

15 July 2020

Available Online:

10 August 2020 effect of long term (32 years) use of mineral fertilizer with and without organic manures were evaluated for monitoring the population of the nitrogen fixing Azotobacter and Azospirrilum spp. community structure, activity of urease, status of available nitrogentheir depletion and buildup in irrigated Vertisols under sorghum -wheat cropping sequence. The All India Co-ordinated Research Project of ICAR have initiated the long term fertilizer field experiment during Kharif 1984-85 at Main Center of Integrated Farming Systems Research Project of Mahatma Phule Krishi Vidyapeeth, Rahuri (Maharashtra). This experiment consists of 12 treatment combinations of only inorganics fertilizers, INM: NPK integrated with organics viz., FYM, Wheat Cut Straw and green manure, farmers practice and unfertilized control with 4 replications in RBD experimental design. The results of the long term experiment revealed that the significant the highest increase in population of Azotobacter ( $31.67 \times 10^{6} \mathrm{cfu} \mathrm{g}^{-1}$ soil) and Azospirillum (22.60 x $10^{6} \mathrm{cfu} \mathrm{g}^{-1}$ soil) were observed in the INM treatment combination of organic manure (FYM)with chemical fertilizer i.e. 50\% NPK through chemical + 50\% N through FYM to Kharif and $100 \%$ RDF to in Rabi and the same treatment recorded highest urease activity (42.09 $\mathrm{mg} \mathrm{NH}_{4}^{+}-\mathrm{N} 100 \mathrm{~g}^{-1}$ soil) over rest of treatments combinations. The occurrence of the dense community of Azotobacter and Azospirrilum in the INM was probably due to higher availability of substrate as carbon which help in increasing microbial population in soil.

\section{Introduction}

After the successful first green revolution soil nutrient management strategies were mainly dependent on the only use of inorganic chemical fertilizers, but its injudicious uses caused a serious threat not only to soil health but also to human health and environment quality. Fertilization is the most common management input for productivity of 
agricultural soils. Organic and inorganic fertilizers are primarily used to increase crop productivity, and in the short-term fertilizer experiments, they do not show a significant effect on microbial community; however, in long-term fertilizer experiments, they can affect the function, community structure and population of soil microorganisms. Biological nitrogen fixation contributes about $60 \%$ of the total nitrogen fixed on Earth, on the contrarily, commercial fertilizers contribute $25 \%$. Long term fertilization usually not only strongly favors the accumulation of bacterial residues but also increases soil microbial biomass, which is a key soil factor that regulates and maintain soil health.

Among the requirement of crops for their productivity after water, nitrogen is most often limiting and a unique and major plant nutrient because unlike the other essential nutrient elements, plant can use it either in the cation form $\left(\mathrm{NH}_{4}^{+}\right)$or in the anion form $\left(\mathrm{NO}_{3}{ }^{-}\right)$. Only a small part of total soil nitrogen occurs in these forms at any one time. The addition of organic matter in the form of manures greatly influences the transformation and availability of nitrogen $(\mathrm{N})$ and several other essential plant nutrients through its impact on the chemical and microbiological properties of soil. Of these the role of organic manures in supplying plant nutrients, particularly $\mathrm{N}$ is most prominent. Crop response to fertilization by $\mathrm{N}$ is inextricably linked to its biogeochemical cycling among its numerous biotic and abiotic forms in soil. Since microbes carry out the most significant $\mathrm{N}$ cycle processes, they have a major impact on the abundance of all forms of soil N (Rai, 2013).

Urease activities in soils have received a lot of attention since it was first reported by Rotini (1935), a process considered vital in the regulation of $\mathrm{N}$ supply to plants after urea fertilization. Urea is one of the most important chemical nitrogen fertilizers; urea hydrolysis in soil is an enzymatic decomposition process by enzyme urease.

Many long-term experiments conducted in India showed increasing yields and accumulation of soil organic carbon and biological properties due to combined application of fertilizers and manures (Manna et al.2005, 2007, Mandal et al., 2007).The hypothesis of the present study was that the effect of long term use of integrated nutrient management practices on the population of Azotobacter and Azospirrilum spp. to Sorghum-Wheat cropping system in Vertisol under semi-arid climatic condition of central India.

\section{Materials and Methods}

\section{Experimental site and treatments}

The long term (32 years) fertilization experiment was initiated in Kharif 1984-85 at Main Center of Integrated Farming Systems Research Project of Mahatma Phule Krishi Vidyapeeth, Rahuri (Maharashtra) by the All India Co-ordinated Research Project (AICRP) of ICAR. The experimental field is located at $19^{\circ} 47^{\prime} \mathrm{N}$ latitude, $74^{0} 18^{\prime} \mathrm{E}$ longitude and at an elevation of about $495 \mathrm{~m}$ above mean sea level. Agro climatically the experimental site is semi-arid with hot and dry summer and cool to mild winter.

The soil of the experimental field has a clay loam texture (sand $22.3 \%$, silt $26.4 \%$, and clay 51.3\%), Typic Haplustert with $\mathrm{pH} 8.2$, organic carbon $0.64 \mathrm{~g} \mathrm{~kg}^{-1}$, electrical conductivity $0.27 \mathrm{dSm}^{-1}$ and bulk density 1.32 $\mathrm{Mg} \mathrm{m}^{-3}$ of soil. The soil available $\mathrm{N}, \mathrm{P}$ and $\mathrm{K}$ were $153,14.2,705 \mathrm{~kg} \mathrm{ha}^{-1}$, respectively. The DTPA-extractable iron (Fe), manganese $(\mathrm{Mn})$, zinc $(\mathrm{Zn})$ and copper $(\mathrm{Cu})$ were 12.95 , $22.10,0.87$ and $3.27 \mathrm{mg} \mathrm{kg}^{-1}$, respectively. 
Sorghum cultivar CSH-9 and wheat HD-2189 were grown in sequence during Kharif and Rabi season respectively at the same site. The experiment consisted of twelve treatments, each replicated four times in randomized block design (RBD) having individual plot size of $12.6 \mathrm{~m} \times 8.10 \mathrm{~m}$. The fertilization treatment details for Kharif and Rabi are given in Table 1.

Dhaincha (Sesbania aculeata) was raised during late summer in a separate field as green manuring crop and incorporated after 55days growth period in respective treatment plots. Calculated amount of organics viz., welled composed FYM and crop residue of wheat straw were uniformly spread and incorporated into the soil with the help of power tiller before sowing of sorghum in respective treatments. The $\mathrm{N}$ content (quantity applied) of FYM, CR and GM used in the experiments over the years at $50 \% \mathrm{~N}$ were $0.50-0.62 \%$ (12.00 to $9.67 \mathrm{t} \mathrm{ha}^{-1}$ ), 0.43 to $0.50 \%\left(13.95-12.00 \mathrm{t} \mathrm{ha}^{-1}\right)$ and $1.7-2.4 \%$ (3.52-2.5 $\left.\mathrm{t} \mathrm{ha}^{-1}\right)$, respectively.

The recommended dose for sorghum and wheat was120:60:40 kg N: $\mathrm{P}_{2} \mathrm{O}_{5}: \mathrm{K}_{2} \mathrm{O}$ ha $^{-1}$. All $\mathrm{P}_{2} \mathrm{O}_{5}$ and $\mathrm{K}_{2} \mathrm{O}$ and a half dose of $\mathrm{N}$ were drilled at sowing. The remaining $\mathrm{N}$ was topdressed at 30 days in sorghum and 21 days after sowing in wheat. The sources of $\mathrm{N}$ fertilizer were urea $(46 \% \mathrm{~N}), \mathrm{P}$ fertilizer were single superphosphate $\left(16 \% \mathrm{P}_{2} \mathrm{O}_{5}\right)$ and for $\mathrm{K}$ fertilizer muriate of potash $\left(60 \% \mathrm{~K}_{2} \mathrm{O}\right)$.

\section{Soil sampling and analysis}

After completion of 32 years of experiment for the proposed study, total 48 samples were taken at $0-15 \mathrm{~cm}$ depth, processed in laboratory and used for chemical properties and for biological parameters stored in deep fridge. These stored samples were further used for microbial population count of Azotobacter and Azospirrilum spp.
(Halvorsun and Zeiglar, 1993), urease activity (Tabatabai and Bremmer, 1972), available N (Subbaih and Asija, 1956). The data Statistical analyzed by using methods of Panse and Sukhatme 1985) are presented in Table 2 with respect of microbial population, urease activities and soil available nitrogen.

\section{Results and Discussion}

\section{Azotobactor population}

The Azotobacter population was significantly varied between $15.75-31.67 \times 10^{6} \mathrm{cfu} \mathrm{g}^{-1}$ soil among the all treatments. As compared to the population of Azospirillum, theall 12 treatments recorded the higher population of Azotobacter. It was also observed that the lowest population (15.75 x $10^{6} \mathrm{cfu} \mathrm{g}^{-1}$ soil) was observed in the unfertilized control plot $\left(\mathrm{T}_{1}\right)$ and significantly the highest population was observed in the treatment received $50 \%$ $\mathrm{RDF}+50 \% \mathrm{~N}-\mathrm{FYM}$ in Kharif and $100 \%$ $\mathrm{RDF}$ in Rabi $\left(\mathrm{T}_{6}\right)$. The treatment $\left(\mathrm{T}_{6}\right)$ also recorded 50.26 per cent more Azotobacter population over the control. The average Azotobacter population due to application of only chemical fertilizers treatments $\left(\mathrm{T}_{2}\right.$ to $\left.\mathrm{T}_{5}\right)$ was $19.24 \times 10^{6} \mathrm{cfu}^{-1}$ soil, which was observed to be increased to $28.75 \times 10^{6} \mathrm{cfu} \mathrm{g}^{-1}$ soil in the treatments $\left(\mathrm{T}_{6}\right.$ to $\left.\mathrm{T}_{11}\right)$ involving integrated use of chemical fertilizers and organic manures. It was also noticed to be low Azotobacter population $\left(17.57\right.$ x $10^{6} \mathrm{cfu} \mathrm{g}^{-1}$ soil) in the farmers practice treatment $\left(\mathrm{T}_{12}\right)$.

Azotobacter is a heterotrophic, aerobic nitrogen fixation bacterium that lives freely. Fertilization with NPK can increase Azotobacter, but if it is done with inorganic fertilizers continuously, it reduces the population (Rao, 1994). The increase in Azotobacter population in INM (FYM + NPK) treatments was probably due to higher availability of substrate as carbon from supplied FYM, intensive rooting activity and 
better soil water status and also nutrient available through chemical fertilizers in INM treatments. The similar observations were reported by Mahajan et al., (2007) and Nerula et al., (2002). In the present study, there was significantly higher number of Azotobacter in the treatment with FYM compared to the other treatments. These results are in accordance with the results published by Mikanova et al., (2009), who showed that nitrogen fertilization in organic form (FYM) increased the counts of Azotobacter spp. Kubat et al., (1997) also documented increasing counts of free-living nitrogenfixing bacteria in a long term experiment in Ruzyne with FYM + NPK treatment as compared to the control.

\section{Azospirrilum population}

The results indicated that the significant variations of Azospirillum population (10.4 to $22.6 \times 10^{6} \mathrm{cfu} \mathrm{g}^{-1}$ soil) were recorded in all treatments combination. The Azospirillum population was observed significantly the highest $\left(22.6 \times 10^{6} \mathrm{cfu} \mathrm{g}^{-1}\right.$ soil $)$ in the treatment which received $50 \% \mathrm{RDF}+50 \%$ N-FYM in Kharif and $100 \%$ RDF in Rabi $\left(\mathrm{T}_{6}\right)$, whereas, the lowest Azospirillum population (10.4 X $10^{-4} \mathrm{~g}^{-1} \mathrm{cfu}$ soil) was observed in absolute control $\left(\mathrm{T}_{1}\right)$. However, the significant increase in the Azospirillum population in treatment $\mathrm{T}_{6}$ was 53.98 per cent over the control.

The average Azospirillum population recorded from the treatments of chemical fertilizers $\left(\mathrm{T}_{2}\right.$ to $\mathrm{T}_{5}$ ) was $15.75 \times 10^{6} \mathrm{cfu} \mathrm{g}^{-1}$ soil which was lower as compare to average population 19.64 x $10^{6} \mathrm{cfu} \mathrm{g}^{-1}$ soil in the treatments involving organics in conjunction with chemical fertilizers $\left(\mathrm{T}_{6}\right.$ to $\left.\mathrm{T}_{11}\right)$. The Azospirillum population (16.1 x $10^{6} \mathrm{cfu} \quad \mathrm{g}^{-1}$ soil) was observed to be low in the farmers practice treatment $\left(\mathrm{T}_{12}\right)$. In general, the study showed that continuous application of NPK fertilizer in combination with FYM, WCS and GM increased the Azospirillum population in soil over control and only 100 per cent RDF treatment $\left(\mathrm{T}_{5}\right)$. The similar results were also reported by the Jayathilake et al., (2006) and Chang et al., (2007).

The present study indicated that the application of manure increased the population of Azospirillum, whereas, application of only NPK fertilizer alone did not affect significantly the population of Azospirillum. Manure application along with NPK fertilizers can increase the content of ammonium in the soil to obtain a high Azospirillum population as compared with the only NPK fertilizer treatment and unfertilized control. These results proved that manure with NPK fertilizers can increase the population of bacteria in the soil. It is expected to increase soil fertility and crop productivity. The present results are in the close confirmatory with the earlier findings of Mujiyati and Supriyadi (2008) and Gurumurthy (2014).

\section{Urease activity}

The urease activity in experimental soil was ranged from 24.24 to $42.09 \mathrm{mg} \mathrm{NH}_{4}{ }^{+}-\mathrm{N} 100$ $\mathrm{g}^{-1}$ soil with the highest urease activity (42.09 mg $\mathrm{NH}_{4}^{+}-\mathrm{N} 100 \mathrm{~g}^{-1}$ soil) reported in treatment $\mathrm{T}_{6}(50 \% \mathrm{RDF}+50 \% \mathrm{~N}-\mathrm{FYM}$ in Kharif and $100 \% \mathrm{RDF}$ in Rabi) and was significantly superior over all other treatments with $42.09 \mathrm{mg} \mathrm{NH}_{4}{ }^{+}-\mathrm{N} 100 \mathrm{~g}^{-1}$ soil value of urease activity. The results revealed that conjoint use of organic manures and mineral fertilizers $\left(T_{6}\right.$ to $\left.T_{11}\right)$ favored the higher urease activity (37.26 mg $\mathrm{NH}_{4}^{+}-\mathrm{N} 100 \mathrm{~g}^{-1}$ soil) as compared to treatments receiving only chemical fertilizer $\left(T_{2}\right.$ to $\left.T_{5}\right)$ which was 31.41 noticed as $\mathrm{mg} \mathrm{NH}{ }^{+}-\mathrm{N} 100 \mathrm{~g}^{-1}$ soil, in farmers practice $\left(\mathrm{T}_{12}\right)$ as $30.19 \mathrm{mg} \mathrm{NH}_{4}{ }^{+}-\mathrm{N}$ $100 \mathrm{~g}^{-1}$ and the least in control $\left(\mathrm{T}_{1}\right)(24.24 \mathrm{mg}$ $\mathrm{NH}_{4}{ }^{+}-\mathrm{N} 100 \mathrm{~g}^{-1}$ soil. 
It was observed that in present study increase in fertilizer level from suboptimum to optimum level significantly increased urease enzyme activities and found to be maximum in 100 per cent recommended dose of fertilizers within the only inorganic fertilizers treatments. Integrated use of mineral fertilizers with FYM $\left(\mathrm{T}_{6}\right)$ showed 20.38, 28.27 with 42.40 per cent increase in soil urease activity as compared to 100 per cent $\mathrm{RDF}$, farmers practice and unfertilized control treatments; respectively.

Soil urease mainly originates from SOM, microbes and plants roots secretion that catalyze hydrolysis of urea fertilizers applied to soil or C-N compounds that are supplied through organics into $\mathrm{NH}_{3}$ with hydrolysis reaction on $\mathrm{C}-\mathrm{N}$ bonds in substrate or substrate complex (urea and urea like $\mathrm{N}$ compounds in soils) supplied through SOM or various applied in INM treatments. In fact, the enzyme activity in the soil is very much governed by the concentration of substrate present and enzyme in the soil.

The rate of urea hydrolysis by soil urease increases with increase in substrate (C-N bounded $\mathrm{N}$ complexes) concentration until the quantity of urea added is saturated and its activity becomes constant (Bremner and Mulvaney, 1978). The differences in urease activity between WCS, GM and FYM at the same level of recommended dose fertilizers was very much governed by their $\mathrm{N}$ content and C: N ratios. Similar results were also reported by Rai and Yadav (2011). The treatments with chemical fertilizers, farmers practice and absolute control recorded lower urease activities than all the INM treatments which could be attributed to lack of sufficient substrate on concentration of enzyme i.e. organic carbon which act as an energy source for prolife rating the microbial population (Kanchikerimatha and Singh, 2001) that governs the concentration of urease and so also concentration of substrate like C-N complexes from various treatments. Thus, the balanced nutrition to crops under integrated use of chemical fertilizers with FYM responsible for better proliferation of roots and microbial population as basis for urease concentration and also availability of substrate of urease were responsible for maximum activity of urease. These results are corroborated with the earlier findings of Manna et al., (2005a), Mandal et al., (2007), Rao and Pathak (1996) and Bhattacharyya et al., (2011).

\section{Soil available nitrogen}

The soil available $\mathrm{N}$ content was varied from 125.20 to $197.05 \mathrm{~kg} \mathrm{ha}^{-1}$ at surface layer. The treatment $\mathrm{T}_{6}(50 \% \mathrm{RDF}+50 \% \mathrm{~N}-\mathrm{FYM}$ in Kharif and $100 \%$ RDF in Rabi) recorded the significantly the highest $\mathrm{N}$ content (197.05 and $177.37 \mathrm{~kg} \mathrm{ha}^{-1}$ ), however, the treatment $\left(\mathrm{T}_{10}\right) 50 \% \mathrm{RDF}+50 \% \mathrm{~N}-\mathrm{GM}$ in Kharif and $100 \%$ RDF in Rabi was significantly at par with $\mathrm{T}_{6}$.

The significant per cent increase in available $\mathrm{N}$ content in soil were 36.44 and 23.00 per cent over the control and farmers practice; respectively. The average increase in available $\mathrm{N}$ content in INM treatments $\left(\mathrm{T}_{6}\right.$ to $\left.\mathrm{T}_{11}\right)$ recoded the higher $\left(189.51 \mathrm{~kg} \mathrm{ha}^{-1}\right)$ than the average value (175.49) in only inorganic $\left(\mathrm{T}_{2}\right.$ to $\left.\mathrm{T}_{5}\right)$ fertilizers treatments, farmers practice $\left(151.72 \mathrm{~kg} \mathrm{ha}^{-1}\right)$ and control (125.20 $\mathrm{kg} \mathrm{ha}^{-1}$ ) at $0-15 \mathrm{~cm}$ soil depth. From the present investigation it was clearly observed that the integrated use of organics with balanced inorganic fertilizers recorded higher available $\mathrm{N}$ content than imbalanced fertilizers. The lower available nitrogen in control and farmers practices was a result of low available nitrogen with continuous cropping without or inadequate fertilization over a long period (32 years) of time (Fig. 1). 
Table.1 Different treatment combinations in the long-term experiment

\begin{tabular}{|c|l|l|}
\hline Treatments & \multicolumn{1}{|c}{ Kharif Sorghum } & \multicolumn{1}{|c|}{ Rabi Wheat } \\
\hline $\mathrm{T}_{1}$ & No fertilizer, no organic matter (control) & No fertilizer, no organic matter (control) \\
\hline $\mathrm{T}_{2}$ & $50 \%$ recommended NPK through fertilizers & $50 \%$ recommended NPK through fertilizers \\
\hline $\mathrm{T}_{3}$ & $50 \%$ recommended NPK through fertilizers & $100 \%$ recommended NPK through fertilizers \\
\hline $\mathrm{T}_{4}$ & $75 \%$ recommended NPK through fertilizers & $75 \%$ recommended NPK through fertilizers \\
\hline $\mathrm{T}_{5}$ & $100 \%$ recommended NPK through fertilizers & $100 \%$ recommended NPK through fertilizers \\
\hline $\mathrm{T}_{6}$ & $50 \%$ recommended NPK through fertilizers $+50 \% \mathrm{~N}$ through FYM & $100 \%$ recommended NPK through fertilizers \\
\hline $\mathrm{T}_{7}$ & $75 \%$ recommended NPK through fertilizers $+25 \% \mathrm{~N}$ through FYM & $75 \%$ recommended NPK through fertilizers \\
\hline $\mathrm{T}_{8}$ & $50 \%$ recommended NPK through fertilizers $+50 \% \mathrm{~N}$ through WSC & $100 \%$ recommended NPK through fertilizers \\
\hline $\mathrm{T}_{9}$ & $75 \%$ recommended NPK through fertilizers $+25 \% \mathrm{~N}$ through WSC & $75 \%$ recommended NPK through fertilizers \\
\hline $\mathrm{T}_{10}$ & $50 \%$ recommended NPK through fertilizers $+50 \% \mathrm{~N}$ through GM & $100 \%$ recommended NPK through fertilizers \\
\hline $\mathrm{T}_{11}$ & $75 \%$ recommended NPK through fertilizers $+25 \% \mathrm{~N}$ through GM & $75 \%$ recommended NPK through fertilizers \\
\hline $\mathrm{T}_{12}$ & Farmer's conventional practice & Farmer's conventional practice \\
\hline
\end{tabular}

FYM-Farm Yard Manure, WSC- Wheat Cut Straw and GM- Green Manuring

Table.2 Effect of 32 years fertilization on Azotobactor and Azospirrilum spp., urease activity and available nitrogen

\begin{tabular}{|c|c|c|c|c|c|c|}
\hline Tr. No. & Kharif Sorghum & Rabi wheat & $\begin{array}{c}\text { Azotobacter } \\
\text { count } \\
\text { (cfu } \times^{6} 10^{6} \mathrm{~g}^{-1} \\
\text { soil) }\end{array}$ & $\begin{array}{c}\text { Azospirrilum } \\
\text { count } \\
\text { (cfu } \times 10^{6} \mathrm{~g}^{-1} \\
\text { soil) }\end{array}$ & $\begin{array}{l}\text { Availabl } \\
\text { e N } \\
\left(\mathrm{Kg} \mathrm{ha}^{-1}\right)\end{array}$ & $\begin{array}{c}\text { Urease activity } \\
\left(\mathrm{mg} \mathrm{NH}_{4}-\mathrm{N} 100\right. \\
\left.\mathrm{g}^{-1} \text { soil hr }^{-1}\right)\end{array}$ \\
\hline & Control & Control & 15.75 & 10.4 & 125.20 & 24.24 \\
\hline $\mathbf{T}_{1}$ & $50 \%$ RDF & $50 \%$ RDF & 17.32 & 14.4 & 161.70 & 29.58 \\
\hline $\mathbf{T}_{2}$ & $50 \%$ RDF & $100 \% \mathrm{RDF}$ & 18.33 & 13.3 & 170.38 & 30.80 \\
\hline $\mathbf{T}_{\mathbf{3}}$ & $75 \%$ RDF & $75 \%$ RDF & 19.75 & 16.9 & 179.92 & 31.76 \\
\hline $\mathbf{T}_{4}$ & $100 \%$ RDF & $100 \% \mathrm{RDF}$ & 21.59 & 17.2 & 189.96 & 33.51 \\
\hline $\mathbf{T}_{5}$ & $50 \%$ RDF+50\% N-FYM & $100 \% \mathrm{RDF}$ & 31.67 & 22.6 & 197.05 & 42.09 \\
\hline $\mathbf{T}_{6}$ & $75 \%$ RDF+25\% N-FYM & $75 \% \mathrm{RDF}$ & 29.17 & 19.8 & 183.82 & 36.49 \\
\hline $\mathbf{T}_{7}$ & $50 \%$ RDF+50\% N-WCS & $100 \%$ RDF & 28.25 & 18.1 & 186.10 & 39.99 \\
\hline $\mathbf{T}_{8}$ & $75 \%$ RDF+25\% N-WCS & $75 \% \mathrm{RDF}$ & 26.84 & 17.5 & 181.23 & 32.81 \\
\hline $\mathbf{T}_{9}$ & $\mathbf{5 0 \%}$ RDF+50\% N-GM & $100 \%$ RDF & 29.25 & 20.3 & 196.50 & 41.42 \\
\hline $\mathbf{T}_{10}$ & $75 \%$ RDF+25\% N-GM & $75 \%$ RDF & 27.34 & 17.8 & 192.37 & 30.80 \\
\hline $\mathbf{T}_{11}$ & Farmers practice & $\begin{array}{l}\text { Farmers } \\
\text { practice }\end{array}$ & 17.57 & 16.1 & 151.72 & 30.19 \\
\hline Mean & & & 23.57 & 17.03 & 176.33 & 33.64 \\
\hline $\mathrm{SE}(\mathrm{m}) \pm$ & & & 0.69 & 0.61 & 1.43 & 0.2 \\
\hline $\begin{array}{c}\text { CD at } \\
5 \%\end{array}$ & & & 1.96 & 1.76 & 4.20 & 0.59 \\
\hline Initial & & & - & - & 157 & - \\
\hline
\end{tabular}


Fig.1 Effect of long term application of manures and fertilizers to sorghum-wheat sequence on $\mathrm{N}$-fixing bacteria

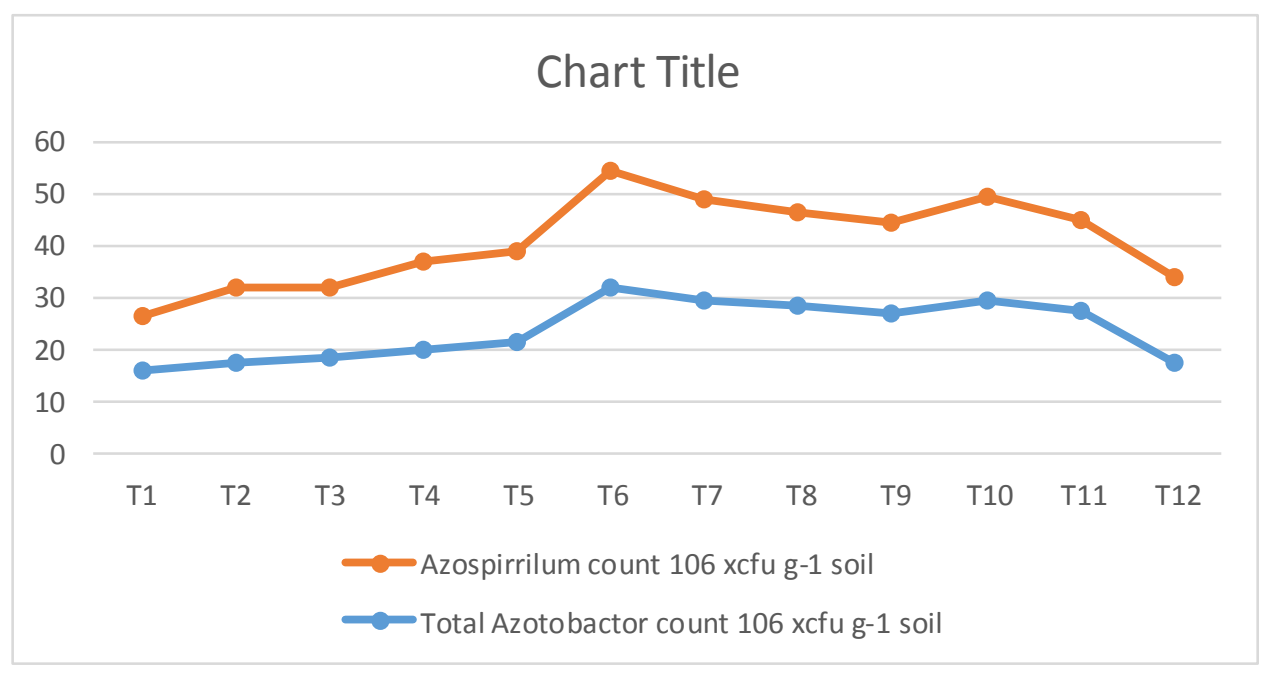

Increase soil available nitrogen in INM had attributed to its direct addition through organics as FYM, GM and WCS, because the favorable soil conditions viz. organic carbon, porosity, water holding capacity, higher population of $\mathrm{N}$ fixing bacteria and urease activity etc. might have helped in the mineralization and reduced nitrogen fixation of soil nitrogen leading to buildup of higher available nitrogen. Thus, from the results obtained, it was seen that the balanced use of NPK fertilizers along with manures was essential for sustaining $\mathrm{N}$ status in Vertisol under cereal - cereal cropping system. The available $\mathrm{N}$ status although showed increase under INM, it has not been increased much due to the prevailing climatic condition accelerating oxidation of organic matter as well as the nature of nitrogen forms in soil and the form of its losses through volatilization and leaching. In this view, the results of present investigation suggest that the maintenance of soil available $\mathrm{N}$ levels is more challenging. This necessitates regular addition of organics for maintenance of soil fertility in the soils of tropical areas. These results are in conformity with the findings of Babhulkar et al., (2000), Tiwari et al., (2002),
Sammy et al., (2003), Gupta et al., (2006), Singh et al., (2007) Urkurkar et al., (2010) and Kharche et al., (2013).

Thus, it is concluded that, the INM practices are proved to be superior in making availability of soil nitrogen on a sustainable basis. Integration of chemical fertilizers by substituting 50 per cent $\mathrm{N}$ through FYM was found the most superior in respect of soil available $\mathrm{N}$ content as compared to GM or WCS. The highest availability of nitrogen in this treatment may be attributed to greater microbial (Azotobacter and Azospirrilum) activities caused by the higher supply of active carbon through FYM source for conversion of organically bound $\mathrm{N}$ to inorganic form that helped in the higher mineralization of soil $\mathrm{N}$ leading to the buildup of available $\mathrm{N}$ in the soil.

Adaption of long term integrated nutrient management practice: 50\% NPK through chemical $+50 \%$ N through FYM to Sorghum and $100 \%$ RDF through chemical to wheat helps to fulfill the nitrogen requirement of Sorghum-Wheat cropping sequence in Vertisol by saving $50 \% \mathrm{~N}$ through the activity 
of Azotobacter and Azospirrilum also reflected in sustaining crop productivity and soil health.

\section{Acknowledgment}

The authors of this paper are very grateful to the all scientists and staff who were involved in conducting this long term experiment during the period of experiment.

\section{References}

Babhulkar, P.S., Wandile, R.M., Badole, W.P. and Balpande, S.S. 2000. Residual effectof long-term application of FYM and Fertilizers on soil properties (Vertisols) and Yield of Soybean, Journal of the Indian Society of Soil Science, 48, (1), 89-92.

Bhattacharya, R., Red, P., Kundu, S., Shrivastava, A.K., Gupta, H.J. and Mitra, S. 2011. Long-term effects of fertilization on Carbon and nitrogen sequestration and aggregate associated carbon and nitrogen in the Indian Himalayas, Nutrient Cycling in Agroecosystems, 86, (1),1-16.

Bremner, J. M. and Mulvaney, R.L. 1978. Urease activity in soil. In R.G. Burns (eds) - Soil enzymes, Academic press, New York. pp. 149-196.

Chang Ed-Haun, Chug Rens-shit and YuongHow Tsat. 2007. Effect of different application rates of organic fertilizer on soil enzyme and microbial population. Soil Science and Plant Nutrition,53,(2), 132-148.

Gupta, V., Sharma, R.S. and Vishvakarma, S.K. 2006. Long-term effect of integrated nutrient management on yield sustainability and soil fertility of rice (Oryza sativa)-wheat (Triticum aestivum) cropping system. Indian journal of Agronomy, 51(3), 160-164.

Gurumurthy, 2014. Long-term application of manures and fertilizers on soil microbial communities and their biological activities in the rhizosphere and bulk soil. M.Sc. (Agri.) Thesis submitted to department of agricultural microbiology university of agricultural sciences Bangalore, pp 1-82.

Halvorsun, H.O. and Ziegler, N.R. 1993.Application of statistics to problems in bacteriology. I. A. means of determining bacterial population by the dilution method. Journal of Bacteriology, 25, 101-121.

Jayathilake, P.K.S., Reddy, I.P., Srihari, D. and Reddy, K.R. 2006. Productivity and soil fertility status as influenced by integrated use of $\mathrm{N}$-fixing biofertilizers, organic manures and inorganic fertilizers in onion, Journal of Agricultural Science, 2(1), 213-219.

Kanchikerimath, M. and Singh, D. 2001. Soil organic matter and biological properties after 26 years of maize-wheat-cowpea cropping as affected by manure and fertilization a combisol in semi-arid region of India. Agriculture, Ecosystems \& Environment, 86(2),155162.

Kharche, V.K., Patil, S.R., Kulkarni, A.A.,Patil, V.S. and Katkar R.N. 2013.Long-term integrated nutrient management for enhancing soil quality and crop productivity under intensive cropping system on Vertisols. Journal of the Indian Society of Soil Science, 61 (4), 323-332.

Kubat, J., Klir, J. and Apfelthaler, R. 1997. Utilization of the long-term field experiment in Prague-Ruzyne in modern agricultural research. Archivfur Acker- and Pflanzenbau and Bodenkunde. 42, 181-191.

Mahajan, S., Kanwar, S.S. and Sharma, S.P. 2007. Long term effect of mineral fertilizers and amendments on microbial dynamics in an Alfisol of 
Western Himalayas. Indian Journal of Microbiology. 47(1), 86-89.

Mandal, B., Majumdar, B., Bandopadhyay, P. K., Hazre, G. C., Gangopadhyay, A., Samantaroy, R. N., Mishra, A. K.,Chowdhuri, J, Saha, M. N. and Kundu, S. 2007. The potential of cropping as affected by manure and fertilization in Cambisol in semiarid region of India. Agriculture, Ecosystems \& Environment. 86,155-62.

Manna, M. C., Swarup, A., Wanjari, R. H., Mishra, B. and Sahi, D. K. 2007. Longterm fertilization, manure and liming effects on soil organic matter and crop yields. Soil \& Tillage Research. 94 (2), 397-409.

Manna, M. C., Swarup, A., Wanjari, R. H., Ravankar, H. N., Mishra, B., Saha, M. N., Singh, Y.V., Sahi, D. K. and Sarap, P. A. 2005. Long-term effect of fertilizer and manure application on soil organic carbon storage, soil quality and yield sustainability under sub-humid and semi-arid tropical India, Field Crops research. 94(2), 397-409.

Mikanova, O., Friedlova, M. and Simon, T. The influence of fertilization and crop rotation on soil microbial characteristics in the long-term field experiment Plant, Soil and Environ, 2009,55(1), 11-16.

Mujiyati and Supriyadi, 2009. Effect of manure and NPK to increase soil bacterial population of Azotobacter and Azospirrilumin chili (Capsicum annum) cultivation. Bioscience. 1(2), 59-64.

NerulaNeeru, Deubel, A., Gransee, A., Behl, R. and Merbach, W. 2002. Impact of fertilizers on total microbiological flora in planted and unplanted soils of longterm fertilization experiment. Archives of Agronomy and Soil Science. (3), 171-180.

Panse, V.A. and Sukhatme, P.V. 1985. Statistical methods for Agricultural
Workers, Revised Edn. ICAR, New Delhi.

Rai S. 2013. Influence of long-term use of fertilizers and manure on nitrogen dynamics in a Vertisolin wheat under rice- wheat cropping system M.Sc. (Agri.) Thesis, submitted to the Indira Gandhi Krishi Vishwavidyalaya, Raipur, (M.P.) India.pp. 1-105.

Rai, T. N. and Yadav J. 2011. Influence of inorganic and organic nutrient sources on soil enzyme activities. Journal of the Indian Society of Soil Science. 59 (1), 54-9.

Rao, D. and Pathak, H. 1996. Ameliorative influence of organic matter on biological activity of salt-affected soils. Arid Soil Research and Rehabilitation. 10 (4), 311-31.

Rao, N.S.S. 1994. Soil microorganisms and plant growth. UI Press. Jakarta. [Indonesia]. p.45.

Rotini O.T. 1935. La trasformazioneen zimaticadell' ureanelterreno. Ann. Labor. Rice Ferm Spallanrani. 3, 143 154.

Sammy, R.K., Singh, M., Tripathi, A.K., Singh, M. and Saha, M.N. 2003. Changes in amount of organic and inorganic fractions of nitrogen in an Eutrochrept soil after long-term cropping with different fertilizer and organic manure inputs. Journal of Plant Nutrition and Soil Science.166, 232238.

Singh, K., Bansal, S.K. and Moinuddin 2007. Effect of continuous cropping for twenty years on some properties of the intensively cultivated alluvial soil and nutrient indexing of rice. Journal of the Indian Society of Soil Science.55, 265269.

Subbaih, B.V. and Asija, G.L. 1965. A rapid procedure for the estimation of available nitrogen in Soils. Current Science. 25, 259-260. 
Tabatabai, M.A. and Bremner, J.M. 1972. Assay of Urease activity in soil. Soil Biology and Biochemistry. 4, 479-487.

Tiwari, A.., Dwivedi, A.K and Dixit, P.R. 2002. Long - term influence of organic andinorganic fertilization on soil fertility and productivity of soybean wheat system in vertisol Journal of the Indian Society of Soil Science.50 (4), $472-475$.
Urkurkar, J.S, Tiwari, A., Chitale, S. and Bajpai, R.K. 2010. Influence of longterm use of inorganic and organic manures on soil fertility and sustainable productivity of rice (Oryza sativa) and Wheat (Triticum aestivum) in Inceptisols. Journal of the Indian Society of Soil Science.80 (3), 208-212.

\section{How to cite this article:}

Nilam B. Kondvilkar, S. R. Patil, A. L. Pharande, B. D. Bhakare and Navle, A. M. 2020. Potential Impact of Long Term Use of Integrated Nutrient Management Practices on the Population of Azotobacter and Azospirillum spp. and urease activity to Sorghum-Wheat Sequence in Vertisol. Int.J.Curr.Microbiol.App.Sci. 9(08): 1502-1511. doi: https://doi.org/10.20546/ijcmas.2020.908.174 